ISSN 2587- 2001 e-ISSN 2618-6187


3 Aylık Ulusal Hakemli - Süreli Dergi -Yıl:5 - Sayı:18 - Kasım 2021

\title{
koynunda büyüdük
}






\title{
ARTEMISİA GENTILESCHI'NIN TABLOLARINDA IYYI İLE KÖTÜNÜNSAVAŞI
}

\author{
THE BATTLE OF GOOD AND EVIL IN ARTEMISIA \\ GENTILESCHI'S PAINTINGS
}

DOI: $10.33404 /$ anasay.1022793

Çalışma Türü: Araştırma Makalesi / Research Article ${ }^{1^{*}}$

Ayşe DURAN*

\section{ÖZ}

Artemisia Gentileschi, 1593-1656 (?) yıllarında arasında yaşamış olup Romalı sanatçı Barok dönemin ünlü ressamlarından Orazio Gentileschi'nin kızıdır. Babasından dolayı resimle iç içe büyüyen sanatçı, Caravaggist ressamların en başarılısı olarak gösterilmektedir. Erken, olgunluk ve geç dönemlerinde Caravaggist üslubu farklı teknik ve yorumlarla geliştiren sanatçı, babasını geri planda bırakan bir anlatıma sahip olmuştur.

Orazio Gentileschi tarafından rahibe olması istenen ancak buna ikna edilemeyen Artemisia, evinde özel resim eğitimi almaya başlamış, bu izole eğitim ilk dönem eserlerine yansımıştır. Sanatçının erken devir tablolarında sınırlı mekân

1- Makale Geliş Tarihi: 12. 11. 2021 Makale Kabül Tarihi: 26. 11. 2021

* Bu çalışma Atatürk Üniversitesi Sosyal Bilimler Enstitüsü Sanat Tarihi Bilim Dalı Batı Sanatı ve Çağdaş Sanatlar Ana Bilim Dalı'nda 2018 yılında tamamlanan "Barok Dönemde Bir Kadın Ressam: Artemisia Gentileschi” isimli Yüksek Lisans Tezinden üretilmiştir./This study was produced from the Master's Thesis titled “A Woman Painter in the Baroque Period: Artemisia Gentileschi" completed in 2018 at Ataturk University, Institute of Social Sciences, Department of Art History, Department of Western Art and Contemporary Arts.

** Doktora Öğrencisi., Atatürk Üniversitesi Sosyal Bilimler Enstitüsü Sanat Tarihi Bölümü, E-posta: ayse.duran16@ogr.atauni.edu.tr ORCID ID (iD https://orcid.org/0000-0002-56044809 
kurgusu göze çarpmaktadır. Olgunluk döneminin başlangıcı olan Floransa yıllarında ise Barok sanatın genel prensiplerini ve Caravaggio etkilerini geliştiren sanatçı, yaşamının son dönemini Napoli'de geçirmiş ve natüralist etkileri sanatında uygulamıştır.

Artemisia Gentileschi'nin günümüze ulaşan kırkın üzerindeki çalışmasında, kadın kahramanların ağırlıklı olduğu görülür. Bu kahramanlar kimi zaman İsrailoğullarını kurtaran, Judith ve Yael gibi cinayet işlemeyi göze alan, kimi zaman da Lucretia gibi uğradıkları tecavüz sonrası kendi canlarına kıyarak toplumda köklü değişiklikler meydana getiren karakterlerdir. Yahudi külliyatı ve antik dönemden özenle seçtiği konularında, kadın kahramanları zekâları ve cesaretleriyle ön plana çıkarmış olan sanatçı, özellikle cinsel suçların da işlendiği eserlerinde kendi portresini kullanmayı tercih etmiştir. 1611 yılında hocası Agostino Tassi tarafından uğradığı tecavüz ve sonrasında yaşadığı mahkeme süreci bu tercihin sebebidir. Mahkemede Tassi yerine kendini yargılanırken bulan Artemisia, mahkeme salonunda suçlanmış ve işkence görmüştür. Yaşadığ1 bu olayı eserlerinde şehvet suçlusu erkekleri cezalandırarak aktaran sanatçı, bu anlamda özellikle 20. yüzyılda ağırlık kazanmaya başlayan kadın hareketinin de sembol isimlerinden biri olmuştur. Sanatçı, eserlerinde bazen kana susamış, bazen Tanrı'nın merhametine kendini bırakmış olan kadın kahramanlarını dramatik bir etkiyle ele almıştır. Öç alan veya bir kurban olan karakterlerindeki zıtlıklar sanatçının farklı ruh hallerinin tuvale yansımasıdır. Burada değinilmesi gereken en önemli husus ise Artemisia Gentileschi'nin sadece bir "kurban" olarak eserlerinde duygusal drama yarattığı düşüncesinin yanlışlığıdır. Sanatçı, yaşadığ kadın kimliği neticesinde geri plana itilmiş olmasına rağmen Barok dönemin en önemli ressamlarından biri olmayı başarmıştır. Yeteneği ve başarılarıyla Floransa Akademisi'ne kabul edilen ilk kadın ressam olma onuruna da erişmiştir.

$\mathrm{Bu}$ çalışma, sanatçı kimliği ve yaşamıyla birçok filme, belgesele ve şiire konu olan Artemisia Gentileschi'nin, hakkında yapılan çalışmalarda ağırlıklı olarak bir "kurban" ya da feminist hareketin sembolü haline getirilen sınırlayıcı aktarımının dışında, sanattaki yetkinliğini incelemeyi amaçlamaktadır.

Anahtar Kelimeler: Artemisia Gentileschi, Barok, Resim, Kadın Ressam ABSTRACT

Roman artist Artemisia Gentileschi, who lived between 1593-1656 (?), is the daughter of Orazio Gentileschi, one of the famous painters of the Baroque 
period. The artist, who grew up with painting due to her father, is shown as the most successful of the Caravaggist painters. The artist, who developed the Caravaggist style with different techniques and interpretations in her early, mature and late periods, had a narrative that left her father in the background.

Artemisia, who was asked to become a nun by Orazio Gentileschi but could not be persuaded, started to take private painting education at her home, and this isolated education was reflected in her early works. The limited space setup is striking in the artist's early paintings. The artist, who developed the general principles of Baroque art and the effects of Caravaggio during the Florence years, which was the beginning of the maturity period, spent the last period of her life in Naples and applied the naturalistic effects in her art.

When Artemisia Gentileschi's works over forty, which have survived to the present day, are examined, it is seen that heroines are dominant in her works. These heroines are the characters who sometimes take the risk of committing murder like Judith and Yael, who save the Israelites, and sometimes, like Lucretia, take their own lives after the rape and bring about radical changes in society. The artist, who has highlighted the heroines with their intelligence and courage in the subjects she carefully selected from the Jewish corpus and antiquity, used her self-portrait especially in her works where sexual crimes are committed. The reason for this is the rape she suffered in 1611 by her teacher Agostino Tassi and the court process she went through afterwards. Artemisia, who finds herself being judged instead of Tassi in the court, was accused and tortured in the courtroom. The artist, who conveyed this event by punishing men guilty of lust in her works, became one of the symbol names of the women's movement, which started to gain importance especially in the 20th century. In her works, the artist deals with the heroines, who are sometimes bloodthirsty and sometimes left to the mercy of God, with a dramatic effect. The contrasts in the avenging or victim characters are the reflection of the artist's different moods on the canvas. However, the most important point to be mentioned here is the falsity of the idea that Artemisia Gentileschi creates emotional drama in her works only as a "victim". Considering the period she lived in, the artist had the honour of being the first woman painter to be accepted to the Florence Academy, as a result of her skills, which enabled her to become one of the most important painters of the Baroque period in her world, in which she was prevented from receiving formal education and left aside as a result of her female identity. 
Except for her restrictive transference, that has predominantly become a "victim" or a symbol of the feminist movement in the studies about her, this study aims to examine the artistic competence of Artemisia Gentileschi, who has been the subject of many films, documentaries and poems with her artist identity and life.

Keywords: Artemisia Gentileschi, Baroque, Painting, Female Painter

\section{Giriş}

Artemisia Gentileschi, 1593 yılında Roma'da dünyaya gelmiş olup Toskanalı ressam Orazio Gentileschi'nin kızıdır (Bissell, 1999, s. 135). Caravaggist bir ressam olan Artemisia, babasının yanında resim çalışmalarıyla iç içe büyümüş (Erkan, 2018, s. 212) ve babasından resim eğitimi almıştır. Orazio Gentileschi, kızının rahibe olmasını istemişse de, Artemisia'nın resme olan ilgisi sonucunda kızına dersler vermeye başlamış, ancak bu dersler atölyede diğer öğrencilerle beraber değil, özel olarak evde verilmiştir. 1611 yılında Orazio Gentileschi, kızının perspektif uygulamalarını öğrenmesi için dönemin en yetkin ressamlarından olan Agostino Tassi'ye öğrenci olmasını sağlamıştır. Eğitimi esnasında Tassi'nin tecavüzüne uğrayan Artemisia, hocası tarafından evlilik vaatleri ile kandırılmış (Elçi Akpınar, 2016, s.15) ve bu istismar bir süre daha devam etmiştir. Henüz 18 yaşında olan Artemisia'nın bu istismara göz yummasının sebebi kendisinin ve babasının itibarından korkmasıdır. Tassi'nin de O'na evlilik vaatlerinde bulunması, Artemisia'nın itibarını ve geleceğini kurtaracağına dair sözler vermesi Artemisia’yı durduran etkenlerdendir. Tecavüzden yaklaşık dokuz ay sonra durumu öğrenen Orazio Gentileschi, Tassi'ye tecavüz suçlaması ile dava açmıştır (Cohen, 2000, s.31). Günümüze ulaşan mahkeme kayıtlarında, Artemisia’nın; “Beni yatağın kenarına itti, bacaklarımın arasına dizini koydu ve böylece bacaklarımı kapatamadım... Bir mendil ile ă̆zımı kapatıp ă̆lamamamı söyledi... Elimden geldiğince çı̆̆lık attım, Tuzia'yı arıyordum”" (Cohen, 2000, s.70) şeklinde ifadeleri bulunmaktadır. Mahkeme kayıtlarından anlaşıldığı kadarıyla tecavüz davası yedi ay sürmüştür. Ancak bu dava süresince Artemisia mağdur değil suçlu konumunda yargılanmış, iffetsizlikle suçlanmış ve defalarca aşağılanmıştır. Dava sırasında mahkeme kararı ile suçlamalarından vazgeçmesi için işkence görmüş ve mahkeme salonunda bekâret kontrolü yapılmıştır (Mavioğlu \& Karbeyaz, 2015, s. 6). Dava sürecinde Artemisia, uğradığ1 tecavüzü ve evlilik vaadiyle kandırılmasını ısrarla tekrar etmiştir. Tüm bunlara rağmen mahkeme salonunda parmaklarına takılan metal yüzüklerin sıkıştırıl- 
ması ile işkence görmüştür. Mahkeme kayıtlarında geçtiğine göre Tassi tüm bu işkenceler sırasında merhamet göstermemiştir. Kendi ifadesinde Artemisia ile ilişkisi olmadığını, onun bir fahişe olarak tanındığını, hatta babası ile ensest bir ilişki içerisinde olabileceğini iddia etmiştir (Elçi Akpınar, 2016, s.15-16).

Davanın ilerleyen dönemlerinde elde edilen bilgiler ışığında Tassi'nin kendi karısını öldürmüş olabileceğine dair şüpheler oluşmuş, baldızı da dâhil olmak üzere farklı cinsel saldırılarda bulunduğu ortaya çıkmıştır. Bu bilgilere rağmen Tassi sadece birkaç ay ceza almış ve Roma'dan sürülmüştür. Ancak kısa bir süre sonra hapisten çıkan Tassi, Roma'da kalıp çalışmaya devam etmiştir (Mavioğlu \& Karbeyaz, 2015, s.143). Mahkeme sürecinden sonra Orazio Gentileschi, kızını Floransalı bir genç olan Pierantonio Stiattesi ile evlendirerek Floransa'ya taşınmışlardır. 1612'de gerçekleșen bu evlilikten sonra Stiattesi, kumar borçlarını ödeyebilmek için soy bağını istismar ederek Artemisia'nın resimlerini borçlarına karşın kullanmıştır (Anderson Silvers, 2010, s. 66). Artemisia'nın bu evliliğinden üç kızı olmuş ancak sadece bir kızı hayatta kalabilmiştir (Bissell, 1999, s. 159).

Floransa'dan, yaklaşık on y1l sonra evliliğini bitirerek Roma'ya geri dönecek olan Artemisia, burada sanattaki yetkinliğini geliştirmiştir. Saygın bir sanatçı olarak hem Genç Michelangelo Buonarroti hem de Mediciler tarafından korunan Artemisia, 1616 y1lında Accademia di Arte del Disegno’ya kabul edilen ilk kadın ressam olma onuruna erişmiştir. Daha öncesinde babasının terk ettiği Caravaggist stili de geliştirmeye devam etmiştir ${ }^{2}$. Floransa'dan ayrıldıktan sonra bir süre Roma'da kalan sanatçı, daha sonra Venedik, Napoli ve İngiltere'ye gitmiş, İngiltere'de bir süre Kral I. Charles'ın yanında çalışmıştır (Anderson Silvers, 2010, s.70). 1639'da babasını kaybeden sanatçı bir süre daha Londra'da kalmış, yaşamının son yıllarını ise Natüralizmin de etkisinde olan Napoli'de geçirmiştir (Honour, Fleming, 2015, s. 579).

Artemisia Gentileschi Roma, Floransa, Venedik gibi bölgelerde çalışmalar yapmış, eserleri ile büyük bir ün kazanmıştır. Tabloları aristokrat çevrelerce aranır hale gelen sanatçı, dönemin önemli simalarından Galileo başta olmak üzere, pek çok düşünür, şair ve yazarın hayranlığını kazanmıştır (Buckley, 2013, s.832). Sanatçı, yapmış olduğu eserlerin büyük bir çoğunluğunda kadınları ya kahraman ya da erkeklerle eşit konumda ele almıştır. Tablolarında kadın karakterler, bilinçli olarak “kadınsı özelliklerden” uzaktır. Kadınlara atfe-

2- https://www.britannica.com/biography/Artemisia-Gentileschi (Erişim Tarihi 01.11.2021). 
dilen, "hassasiyet, çekingenlik ve zayıflık" gibi ruhsal durumlar onun eserlerine "asil, cesur ve güçlü” kadınlar olarak yansımıştır (Bissell, 1999, s.112). Eserlerinde kana susamış sahneleri betimlemiş, kadın kahramanlarını erotik, kanlı ve bir kurban ya da intikam alır halde tasvir etmiştir (Cumming, 2008, s.172). Barok'un zitlıklar prensibine uygun olarak, eserlerinde yoğun duygusal anlatımları karşıt duygularla yansıtan sanatçı, Caravaggio'nun izinde, Natüralizmi duygusal drama ile bütünleştirerek karakterlerini resmetmiştir. Gentileschi'nin eserlerinde, kutsal figürler sıradan insan tiplemeleri ile ele alınmış, kutsallık idealize edilmemiştir. Eserlerinde kutsallık fiziksel olarak değil, seyirciye aktarılan ruhsal bir ifade ile idealleştirilmiştir.

Artemisia Gentileschi, yaşamış olduğu olayları tablolarına aktarmıştır. Tevrat, İncil ve mitolojiden seçtiği kadın anlatılarında konularını özenle seçmiştir. Tablolarına aktardığı bu bilinçli öykülerde bazen uğradığı tecavüzün intikamını, şehvet suçlusu bir figürü öldürerek almış, bazen köleliğe karşı kadın kahraman imajını vurgulamıştır. Seçmiş olduğu kadınlar arasında aynı zamanda zekâsı ile erkekleri alt eden figürlere yer vermiştir. Bu kadın figürlerinin bazılarında kendi portresini kullanan sanatçı, güçlü kadın imajı ile kendini bütünleştirmiştir.

$\mathrm{Bu}$ çalışmada Artemisia Gentileschi'nin günümüze ulaşan kırkın üzerindeki eseri arasından, özelinde kadın kahramanların "kötülükle savaşının" betimlediği eserleri yer almaktadır. Artemisia'nın, Barok'un zıtlıklar prensibine uygun olarak farklı ruh hallerinde ele almış olduğu kahramanları arasında, farklı dönemlerde resmettiği aynı konulu eserleri de bulunmaktadır. Bunlar, sanatçının kişisel gelişimini gözler önüne sermesi açısından da son derece önemlidir. Aynı konulu tablolarında, sadece teknik yetkinlikte ulaştığı seviye değil, aynı zamanda ifadesel anlatımda değişen dünyasını da izlemek mümkündür. Bu çalışmada yer verilen eserler; üç kez resmetmiş olduğu Suzanna ve Yaşlılar, dört kez resmetmiş olduğu Judith, iki kere resmettiği Lucretia ve birer kez resmettiği, Yael ve Sisera, Ahoşveroş'un Huzurunda Ester ile Satyr ve Corisca'dır. Sanatçının kişisel gelişimini takip edebilmek açısından tanıtımı yapılan eserler kronolojik sırayla değil, benzer eserleri gruplandırılarak anlatılmıştır.

\section{Suzanna ve Yaşlılar}

Suzanna ve Yaşlılar, Tevrat'ın Daniel Kitabı'nda aktarılan bir öyküdür. Burada belirtildiğine göre Babilli Yoakim'in karısı olan Suzanna, son derece inançlı ve iffetli bir kadındır. Zengin bir adam olan kocası Yoakim toplum tara- 
findan saygı duyulan ve güven uyandıran biridir. Yoakim ve Suzanna'nın evi insanların bir araya geldikleri bir toplanma yeri ve toplumdaki davaların görüldüğü bir nevi mahkemedir. Bu davaları da iki yaşlı yargıç karara bağlamaktadır. Ancak bu iki yaşıı yargıç Suzanna'ya karşı saplantı haline gelen arzular beslemeye başlamışlar ve bir gün Suzanna'ya kendileriyle birlikte olmasını teklif etmişlerdir. Suzanna bu teklifi reddedince ona iftira atacaklarına dair tehditte bulunmuşlardır. Suzanna tüm bu baskılara rağmen onları reddetmiş, iftira sonucunda mahkemede yargılanmış ve ölüm cezasına çarptırılmıştır. Daniel Kitabı'nın devamında, Peygamber Daniel'in zekâsı ile yargıçların yalanını ortaya çıkardığı ve kendini Tanrı'nın merhametine bırakmış olan Suzanna'yı kurtardığ anlatılır. Yargıçlar, Suzanna'yı bahçedeki ağacın altında başka bir erkekle gördüklerini beyan etmişlerdir. Peygamber Daniel ayrı ayrı yargıçları sorgulayarak, o ağacin hangi ağaç olduğunu sormuştur. Yargıçlardan biri "küçük bir zamk ağacı", diğeri ise "meşe ağacı" olduğunu söylemiş ve yalanları ortaya çıkmıştır. Suzanna'nın masumiyeti kanıtlanmış ve yargıçlar idama mahkûm edilmiştir³.

Artemisia'nın, erken dönem, olgunlaşma dönemi ve geç dönem olarak adlandırılabilecek olan üç ayrı döneminde resmettiği Suzanna ve Yaşlılar, ressamın sanat hayatındaki gelişimini göstermesi bakımından dikkat çekicidir. 1610-11 yılında resmetmiş olduğu ilk tablosunda (Resim 1), mekân kurgusu açısından, tablonun arka kısmında yer alan gökyüzü ve bulutlar, açık hava mekânını belirtilse de, kurguda bir zayıflık göze çarpmaktadır. Doğa betimlemesinin sinırlı tutulduğu eserde, Suzanna taş bir blok üzerine oturmuş, kendisini yaşlı yargıçlardan korumak ister bir haldedir. Barok'un ifadesel anlatımının ön planda olduğu eserde, Suzanna'nın yüzünde tedirgin ve iğrenmiş bir ifade yer almaktadır. Arka kısımda yer alan iki yargıçtan daha genç olanı, ötekinin kulağına bir şeyler fisıldarken resmedilmiştir. Bu, Artemisia'nın tablolarında sıkça görülen "an ressamlığının” yansımasıdır. Tabloda, Caravaggio ile birlikte yaygınlaşan, idealize edilmeyen figür anlayışına uygun olarak, Suzanna sıradan bir tiplemeyle ele alınmıştır. Eserde dikkat çeken bir diğer husus, ışığın tabloda her yere yayılmış olmasıdır. Bu durum, sanatçının bilinen ilk eserini oluşturan bu tabloda henüz Caravaggist üslubun oturmamış olduğunu gösterir.

Artemisia'nın olgunluk döneminde resmettiği bir diğer Suzanna ve Yaşlılar tablosunda (Resim 2) ise mekân kurgusu çok daha zengindir. Dönemini yansıtan ve kısmen tabloda görülen bir su yapısı, arka kısımda gökyüzü betimlemesi ile ağaç ve Suzanna'nın ayaklarını koymuş olduğu havuz ile genişıletilen

3- https://www.catholic.org/bible/book.php?bible_chapter=13\&id=34 (Erişim Tarihi: 06.11.2021) 
mekân kurgusuna, sanatçının Caravaggist üsluba uygun olarak 1şığ1 parçaladığ1 bir kontrast da dâhil olmuştur. Suzanna' da yoğunlaşan 1şık, ondan uzaklaştıkça soluklaşmıştır. Eserde, Suzanna, ikonografiye uygun olarak, kendini Tanrı'nın merhametine bırakmış ve yaşlı yargıçlara boyun eğmeyen bir ifadeyle resmedilmiştir. Sanatçının bu eserinde, ilk tablodaki sınırlı renk uygulamasının da zenginleştiği ve Barok’un şaşasına uygun parlak renklerin tercih edildiği görülür.

Üçüncü Suzanna ve Yaşlılar tablosunda (Resim 3) ise sanatçının ilk iki tabloya nazaran kasvetli bir anlatıma gittiği görülür. Uygulanan renk ve 1 ş1k etkisi ile vurgulanan bu durum, Barok'un duygusal drama ile idealize edilen anlatımına uygundur. Tabloda bir diğer farklılık, Suzanna'nın resmediliş biçiminde yer alır. İlk tabloda, kendini yargıçlardan korumaya çalışan ve yüzünde tedirgin bir ifadeye yer verilen Suzanna, ikinci tabloda, üzerini örtmeye çalışan ve kendini Tanrı'nın merhametine bırakan bir anlatıma sahiptir. Ancak üçüncü tabloda yer verilen teatral aktarım, bu iki anlatımdan farklı olarak, Suzanna'da yer verilen öfke ile ifade bulmuştur. Artemisia'nın her üç eserinde de vurgulanan figür, sadece teknik açıdan değil aynı zamanda ifadesel anlatımla da Suzanna olmuştur. Üç tabloda da yaşlı yargıçlar, içlerinde taşıdıkları kötülüğü yansıtmamaktadırlar. Bu açıdan, aynı konuyu işleyen Rubens'in eserinde, (Resim 4) şeytani kötülüğün temsilcisi olan yargıçlar, Artemisia'nın eserinde yerini arzular1nın esiri olmuş figürlere bırakmış, Rubens'in vurguladığı yargıçların kötülüğü, Artemisia'nın ön plana çıkardığı ise Suzanna'nın masumiyeti olmuştur.

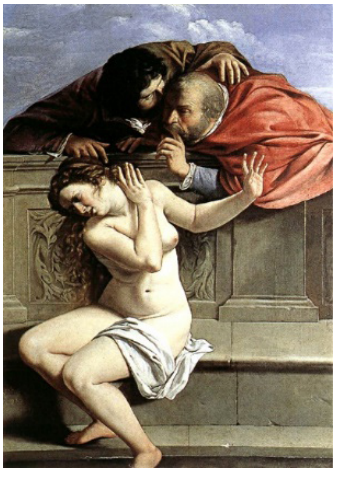

Resim 1: Artemisia Gentileschi, "Suzanna ve Yaşlılar", 1610/11, Tuval Üzerine Yağlı Boya, 170 x 121 $\mathrm{cm}$, Schloss Weissenstein, Pommersfelden.

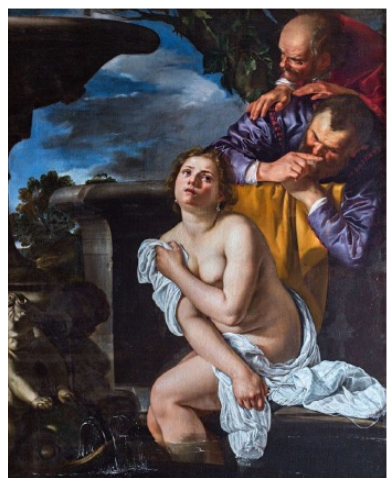

Resim 2: Artemisia Gentileschi, "Suzanna ve Yaşlılar", Tuval Üzerine Yağlı Boya, 161,5 x $123 \mathrm{~cm}$, 1622, Exeter Marquess Koleksiyonu, Lincolnshire (Christiansen \& Mann, 2013, s. 355).

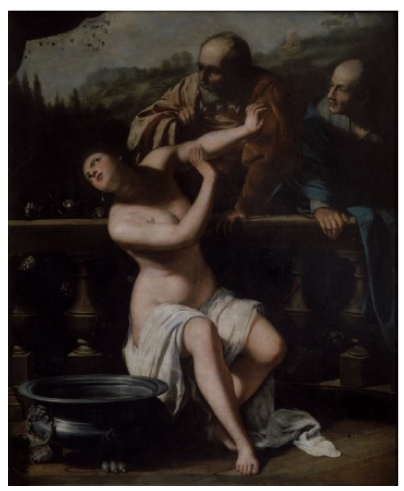

Resim 3: Artemisia Gentileschi, "Suzanna ve Yaşlılar", Tuval Üzerine Yağlı Boya”, 205 x 168 cm, 1649, Moravskâ Galerie, Brno (Modesti, 2016, s. 139). 


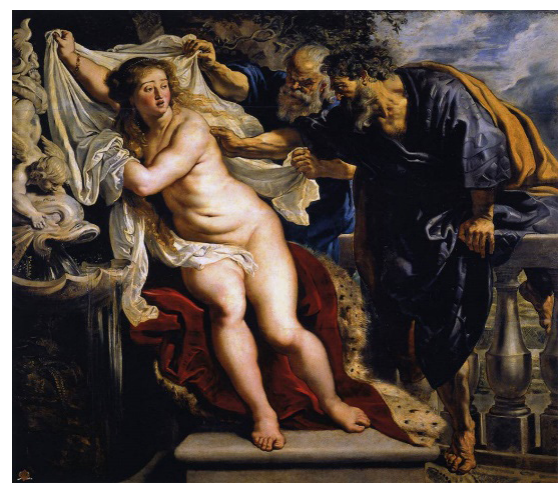

Resim 4. Peter Paul Rubens, "Suzanna ve Yaşlılar”, Panel Üzerine Yağlı Boya, 198 x 218 cm, 1609/1610, Real Academia de Ballas Artes de San Fenando, Madrid.

\section{Judith ve Holofernes}

Museviliğin apokrif metinlerinden olan Judith'in Kitabı'nda İsrailoğullarını kölelikten kurtaran Yahudi bir kadın olan Judith'in hikâyesi anlatılmaktadır. Metinde belirtildiğine göre Asurlular kendilerine boyun eğmeyen İsrailoğullarına General Holofernes komutasında bir ordu göndermiştir. İsrailoğullarını çaresiz bırakan bu durum karşısında, Yahudi dul bir kadın olan Judith, halkının karşı çıkmasına rağmen hizmetçisi Abra ile beraber bir plan yapar ve Asurlulara sığınır. Amacı, General Holofernes'in dikkatini çekerek onu öldürmektir. Holofernes'in çadırına girmeyi başaran Judith, generalin kendisine karşı arzu duymasını sağlar ve onu sarhoş eder. General yatağına uzanıp Judith’i bekler, Judith ise Holofernes' in kılıcını alarak kendinden geçmiş olan generalin başını keser. Holofernes'in öldügüün gören ordusu dağ1lır ve İsrailoğulları kölelikten kurtulur. Judith, "Rabb, bugün bir kadın eliyle size yardım edecek” sözünü yerine getirir (Book of Judith, Chapter: 12; s. 17, 18, Chapter: 13; s. 4, 5, 8, 9, 10). Gentileschi tarafından dört kez resmedilen Judith'in hikâyesi, sanatçının Caravaggio'nun izinden giden üslubunu en yalın haliyle ortaya koyan tablolardandır.

Artemisia'nın erken ve olgunluk döneminde dört kere resmetmiş olduğu Judith tabloları, sanatçının yaklaşık on yıl gibi bir sürede Caravaggio etkisini ne denli başarılı bir şekilde ele aldığını gösterir. Sanatçının Caravaggio'dan etkilenmesine rağmen teknik açıdan ve ifadesel aktarımdan dolayı kendine has bir üslup meydana getirmeyi başarmış olması dikkat çekmektedir. 1612-13 yılında resmettiği ilk tabloda (Resim 5) Judith'in tam da Holofernes'in başını kesme 
anını aktaran sanatçı, "an ressamlığına" uygun olarak Holofernes'in yüzünde yer verdiği dehşet ifadesiyle olayın trajik yönünü vurgulamıştır. Tabloda hem Judith hem de hizmetçisi Abra yaptıkları işten son derece emin bir şekilde ele alınmışlardır. Bir insanı öldürmenin psikolojik alt yapısını yansıtan Caravaggio'nun Judith'indeki (Resim 9) kararsızlık, Artemisia'nın eserinde yerini, halkı için göze aldığı şeyi "sıradanlaştırmış" bir kendinden emin olma haline bırakmıştır. Caravaggio'nun eserinde, Judith'in yüzünde yer verilen üzgün ve kararsız ifadeye zıt şekilde yaşlı hizmetçi Abra, cinayetin azmettiricisi konumunda, elindeki bezi hınçla sıkan ve Holofernes'e öfkeyle bakan bir ifadeye sahiptir. Bu bir nevi, gençliği ve güzelliğiyle ön planda olan Judith'in bilinçli bir kötülüğe bulaşamayacağını ve bir azmettiricisinin olması gerektiği ile ilişkilidir. Oysa Artemisia'nın eserinde Abra, Judith'in planına uyan bir iş birlikçidir ve her iki karakter de genç ve güzel olarak ele alınmıştır. Artemisia'nın ikinci Judith anlatımında ise (Resim 6) cinayet anından sonrası aktarılmıştır. Benzer şekilde yaptığı işten memnun olan Judith, az önce bir insanı öldürmüş olmasına rağmen umursamaz bir şekilde Holofernes'in kılıcını omuzuna atmıştır. Sanatçının üçüncü Judith tablosu (Resim 7) ilkiyle benzer bir temaya sahiptir. Ancak özellikle üçüncü tabloda, sanatçının teknik açıdan büyük bir ilerleme elde ettiği görülür. İlk tabloda (Resim 5) yer alan kılıç, çarşafla bütünleşmiş ve hacmi olmayan çizgisel bir ögedir. Üçüncü tabloya gelindiğinde (Resim 7) ise kılıcın ayrı bir unsur olarak başarılı bir şekilde aktarıldığı görülür. İlk tabloya kıyasla üçüncü tabloda 1şık daha başarılı kırılmalara uğramıştır. Barok’un teatral aktarımına büyük bir katkı sağlayan 1şık, tablolarda belirli bir alandan kırılmalara uğrayarak yayılan ve bu yönüyle aktarılan konuya uygun şekilde anlatımı kuvvetlendiren bir unsur olmuştur. Bu açıdan Artemisia'nın dördüncü Judith betimlemesinde (Resim 8), 1şı̆̆ın mum aracılığıyla doğrudan Judith'e, ondan kırılmalara uğrayarak hizmetçisine ve yine kırılmalar halinde mekâna yayıldığı görülür. Tabloda kullanılan renkler ve 1şık-gölge etkisiyle o anda yaşanan gerilim net bir şekilde yansıtılmıştır. Holofernes'in kesik başını beze saran Abra ve elini muma doğru götürerek 1şı̆̆ 1 gözlerinden uzak tutmaya çalışan Judith dışarı doğru bakmaktadırlar. Olayın Holofernes'in çadırında meydana geldiği düşünülürse, dışarıda Holofernes' in askerleri bulunmaktadır. Judith ve Abra bir ses duymuş gibi dışarı bakmaktadırlar ve Judith, Holofernes'in kılıcını saldırmaya hazır vaziyette tutmaktadır. Bu anlatım, 1şık etkisiyle birleşince seyircide gerilimi artıran bir betimlemeye dönüşmüş, sanatçının ilk üç tablosundaki din- 
ginliğin yerini gerilim almıştır. Judith betimlemelerinde, özellikle Resim 5 ve 7'de kendi portresini kullanmış olduğu düşünülen sanatçı, kendini, köleliğin bayraktarı olarak kabul edilen ve arzularının esiri olan bir erkeği öldüren Judith ile özdeşleştirmiştir. Bu durum, Tassi'den tabloları yoluyla intikam alması olarak yorumlanabilir.

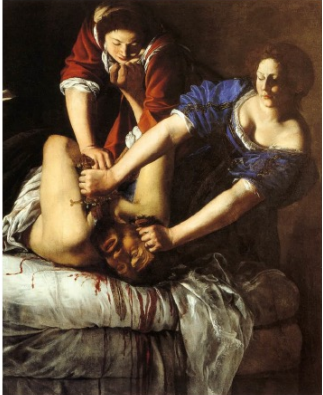

Resim 5: Artemisia Gentileschi, "Judith'n Holofernesi Öldürmesi”, Tuval Üzerine Yağlı Boya, 158,8 x 125,5cm, 1612/1613, Museo di Capodimonte.

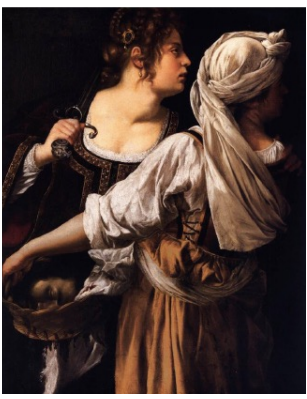

Resim 6: Artemisia Gentileschi,"Judith ve Hizmetçisi”, Tuval Üzerine Yağlı Boya, $114 \times 93,5 \mathrm{~cm}$, 1614/1620, Palazzo Pitti, Floransa.

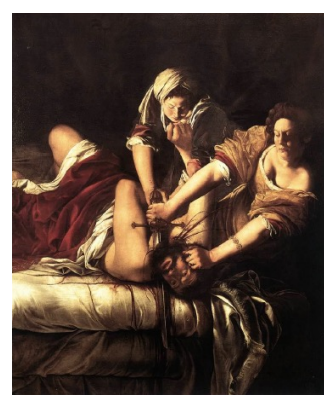

Resim 7: Artemisia Gentileschi,"Judith'in Holofernes'i Öldürmesi", Tuval Üzerine Yağlı Boya, 199 x $162 \mathrm{~cm}, 1621$, Galleria degli Uffizi, Floransa.

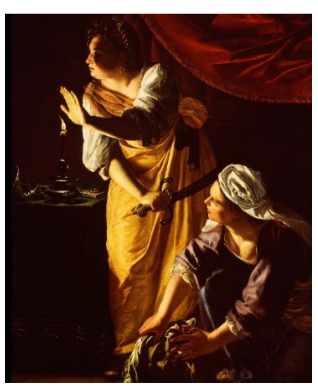

Resim 8: Artemisia Gentileschi, "Holofernes'in Başı ile Judith ve Hizmetçisi", Tuval Üzerine Yağlı Boya, $182,2 \times 142,2 \mathrm{~cm}$, 1623/1625, Detroit Institute of Arts.

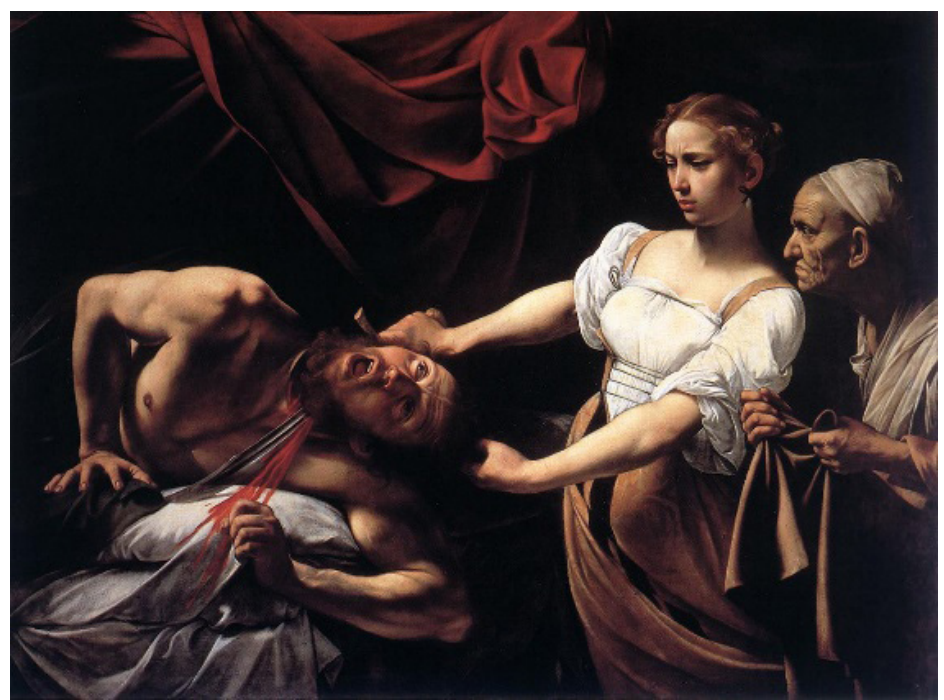

Resim 9. Caravaggio, "Judith'in Holofernes' in Başını Kesmesi”, Tuval Üzerine Yağlı Boya, 145 x 195 cm, 1598, Galleria Nazionale d'Arte Antica, Roma (Erkan, 2018, s. 212). 


\section{Yael ve Sisera}

Yael ve Sisera'nın öyküsü Kitab-1 Mukaddes'in Hâkimler bölümünde geçmektedir. Burada belirtildiğine göre, Kenanlı Kral Yavin'in ordu komutanı olan Sisera, İsrailoğulları'na karşı savaşır. İsraillilerden Barak'ın karşısında bozguna uğrayan Sisera savaş alanından kaçar ve Kenlilerden Hever'in karısı olan Yael'in çadırına sığınır. Yael, Sisera'nın kim olduğunu anlar ve ona süt ikram edip çadırına alır. Sisera Yael'e güvenir ve uykuya dalar. Yael eline aldığı bir çadır kazığını Sisera'nın şakağına dayar ve kazığı yere çakana kadar tokmakla vurarak Sisera'yı öldürür. Bu öykü, peygamber Deborah'ın, “Rab, bir kadın eliyle size yardım edecek” sözünün yerine gelmesini ifade eder (Hâkimler: 4; s. 1- 6, 8,-9, 15, 17-23).

Artemisia Gentileschi'nin cinayet temalı bir diğer eseri Yael ve Sisera'dır. Sanatçının olgunluk dönemi eserlerinden olan tabloda mekân kurgusu oldukça sınırlı tutulmuştur. Her ne kadar Yael ve Sisera öyküsünde, olayın bir çadırda meydana geldiği belirtilse de, arka kısımda yer alan pilaster ve duvar örgüsü, sanatçının ikonografik gerçeklikten ziyade, ifadesel etkiyi ön plana ald1ğını göstermektedir. Artemisia tablosunda, yerde uzanmış uyur şekilde betimlediği Sisera'nın şakağına çadır kazığını çakmak üzere olan Yael'i resmetmiştir. Sisera, Yael'e son derece güvenmiştir. Bunun en belirgin kanıtı, hiçbir önlem almadan uykuya dalması ve kılıcını kendinden uzak bir yere bırakmış olmasıdır. Yael ise ne bu güvene ihanet edecek ne de birazdan bir insanı öldürecek olmasını belirten bir ifadeye sahip değildir. Judith anlatımında olduğu gibi, Yael de yaptığı işten memnun ve kendinden emin bir halde tabloya aktarılmıştır. Aynı konuyu işlemiş olan Alessandro Turchi'nin eserinde (Resim 11) hınçla Sisera'y1 öldürmek üzere olan Yael, Artemisia'nın eserinde sıradan bir iş yapar şekilde ele alınmıştır. Sol elindeki çadır kazığını Sisera'nın şakağına dayamış olan Yael, sağ eliyle çekici havaya kaldırmıştır. Bu açıdan sanatçı, bir sonraki "anda" çadır kazığını Sisera’nın şakağına çakacağı anı seyircinin gözünde canlandırmayı başarmıştır. Artemisia'nın tablosundaki Yael sadece kendinden emin olma haliyle değil, aynı zamanda yüzünde yer alan gülümsemeyle de Turchi'nin eserinden ayrılır. Artemisia'nın Yael betimlemesi, vahşi bir cinayet anına giderken yer verdiği ifadesel anlatımla, seyircide rahatsızlık meydana getiren bir aktarıma sahiptir. 




Resim 10: Artemisia Gentileschi, "Yael ve Sisera", Tuval Üzerine Yağlı Boya 86 x 125cm, 1620, Szêpmüvêszeti Museum, Budapeşte (Christiansen \& Mann, 2013, s. 344).

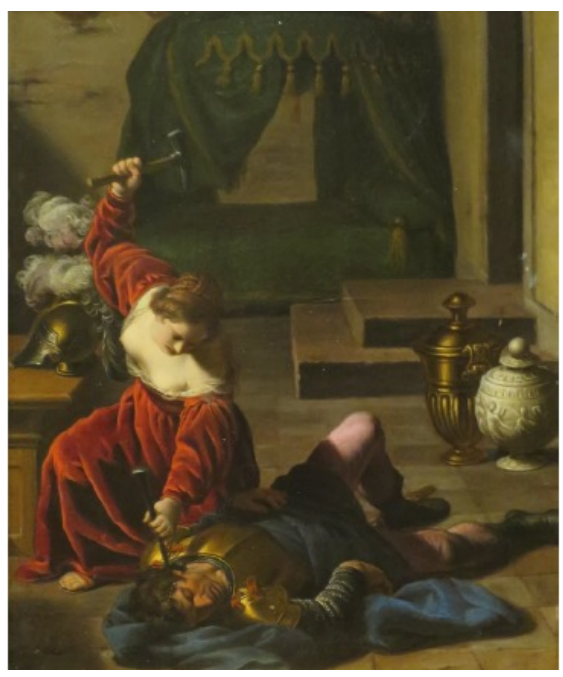

Resim 11: Alessandro Turchi, "Yael ve Sisera", Bakır Üzerine Yağlı Boya, 1600/1610, Dayton Art Institute, ABD.

\section{Lucretia}

Artemisia'nın tekli ve çoklu figürlerden oluşan eserleri arasında kadın anlatımları yoğunluktadır. Bunlar arasında konusunu Roma tarihinden alan Lucretia'nın öyküsü iki kere resmedilmiştir. Geleneksel anlatıda soylu bir aileye mensup ve evli olan Lucretia'nın, Roma kralının oğlu Sextus Tarquinius tarafından tecavüze uğradığı anlatılmaktadır. MÖ 509 yılında meydana geldiği 
kabul edilen olayda, Tarquinius, Lucretia'nın odasına zorla girmiş ve onunla birlikte olmayı kabul etmezse onu öldüreceğini ve ölü bedenini siyahi bir kölenin yanına yatırarak ailesi ile birlikte itibarını yerle bir edeceğini söylemiştir. Lucretia bu tehditler sonucu yardım isteyememiştir. Tarquinius'un tecavüzünden sonra olayı ailesine anlatan Lucretia, bir bıçağı göğsüne saplayarak intihar etmiştir. Onun ölümü, ailesinin ve halkın monarşiye karşı ayaklanmasına ve Roma Cumhuriyeti'nin kurulmasına vesile olmuştur ${ }^{4}$.

Konusunu tarihi bir olaydan alan Lucretia'nın hikâyesi, Artemisia'nın farklı ruh halleriyle ele aldığ 1 iki tabloya yansımıştır. Ancak ilk yapılan tablo (Resim 12), ikinci tablodan (Resim 13) kronolojik olarak daha sonraya ait bir anı anlatmaktadır. İlk tabloda tecavüz olayından sonrasını, Lucretia'nın kendisini öldürecek olduğu anı resmeden sanatçı, kapalı bir mekânda yer verdiği Lucretia'da öfkeli bir anlatıma gitmiştir. Yaşadığı trajik olay ve biraz sonra kendisini öldürecek olmasına rağmen sanatçının yer verdiği bu öfke, kendi hayatından izler barındırıyor olabilir. Sanatçının, Sextus'un tehditleri sonucu sessiz kalmak zorunda kalan Lucretia'nın neler hissetmiş olabileceğine dair kendi tecrübelerinden yola çıktığı düşünülebilir. Agostino Tassi'nin vaatleri ve "itibar" üzerine Artemisia'yı manipüle etmiş olmasından yola çıkan sanatçı, Lucretia'da kendine dair bir anlatıma yer vermiş olmalıdır. Bunun yanı sıra, Lucretia betimlemesinde, sanatçının kendi portresini kullandığı da ifade edilmektedir. Geleneksel anlatıda, tecavüzden sonraki gün ailesinin yanında intihar eden Lucretia, Artemisia'nın eserinde, odasında yalnız başına ve intihar etmek üzereyken betimlenmiştir. Sol elinde havaya doğrulttuğu hançeri ve sağ eliyle göğsünü hınçla sıkmakta olan Lucretia'nın yüzünde, ne hüzün ne de ölecek olmanın korkusu vardır. Lucretia başını yukarıya doğru kaldırmış ve öfkeli bir yüzle bakmaktadır. Bu anlatım, Lucretia'nın sadece başına gelen olaya ve Sextus'a olan öfkesini değil, aynı zamanda kendine de öfkeli olduğunu göstermektedir. Özellikle göğsünü hınçla tutması bu kanıyı kuvvetlendirir.

Artemisia'nın ikinci Lucretia tablosu ise (Resim 13) Lucretia'nın Sextus tarafından tehdit edildiği anı aktarmaktadır. Tamamen çıplak olarak betimlenmiş olan Lucretia yatağa hafif bir şekilde uzanmış, eliyle Sextus'un kendisine doğrulttuğu bıçağı durdurmak ve kendini korumak ister haldedir. Tablonun köşesinde ise Sextus'un Lucretia'yı tehdit ettiği sırada, "ölü bedenini siyahi hizmetçinin yanına koyacağını” söylemesine istinaden, siyahi bir hizmetçi, per-

4- https:/www.britannica.com/topic/Lucretia-ancient-Roman-heroine (Erişim Tarihi: 06.11.2021) 
deyi aralamış olanları izlemektedir. Sextus'un beden dilinde ve yüzünde şeytani kötülüğün ifadesi yer almaktadır. Aynı konuyu resmeden Luca Giordano'nun eserinde (Resim 14) Sextus'un yüzünde, yaptığı eylemin tam tersi şekilde acı çeken bir ifade vardır. Bu, Sextus'u bilinçli kötülükten çıkaran ve onu arzularının peşinde bir "kurban" olarak yansıtan bir aktarımdır. Oysa Artemisia'nın eserinde, Sextus'un yüzünde yaptığı şeyin farkında olan bir ruh hali ve bundan da ötesi içindeki kötülüğün donuk bir yüzle ortaya konduğu bir anlatım vardır. Yine Giordano'nun eserinde, Sextus bıçağı daha az tehditkâr bir halde tutmuş ve diğer eliyle Lucretia'ya sarılır şekildedir. Artemisia'nın eserinde ise bir tecavüzcünün ruh halini bilmesi kaynaklı bir dehşet vardır. Sextus son derece kararlı bir halde bıçağın tutarken, diğer eliyle de Lucretia'nın bacaklarını açmaya çalışmaktadır. Bu, Sextus'un iğrenç amacını gösteren bir anlatımdır. Artemisia'nın eserinde 1şık arka planda neredeyse hiç görülmez. Arka planın bu karanlık atmosferine rağmen, özellikle Lucretia' da vurgulanan 1 şık, olayın trajik boyutunu ortaya koymaktadır.

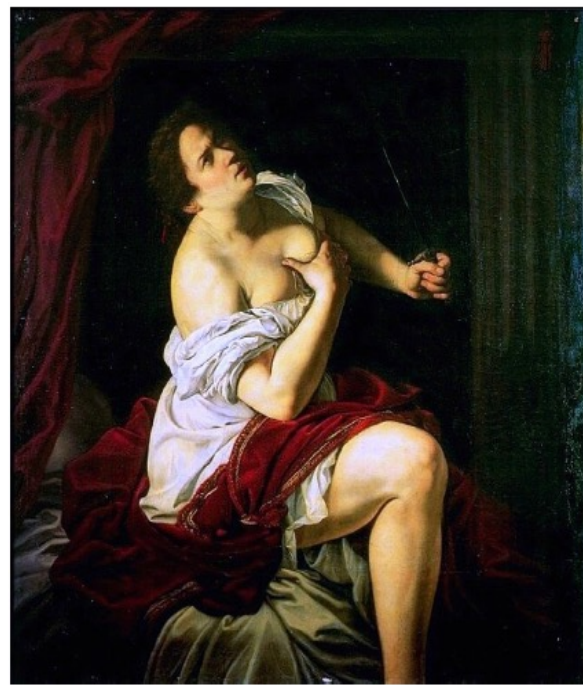

Resim 12: Artemisia Gentileschi, "Lucretia”, Tuval Üzerine Yağlı Boya 100 x 77 cm, 1623/1628, Girolamo Etro, Milan.

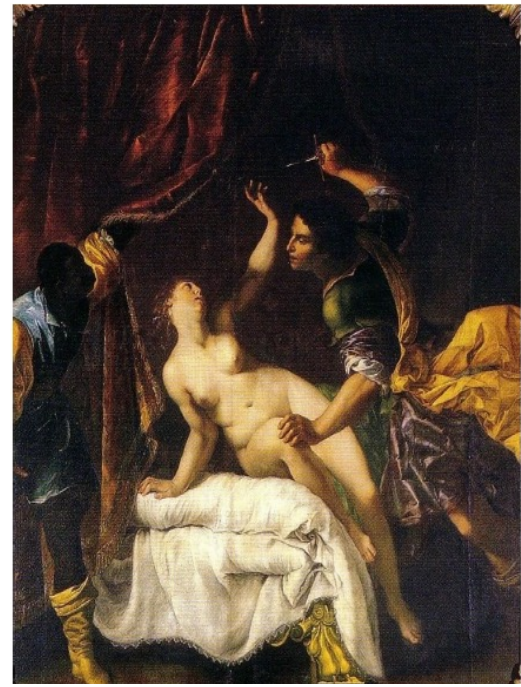

Resim 13: Artemisia Gentileschi, "Lucretia'ya Tecavüz”, Tuval Üzerine Yağı Boya, 261 x 226 cm, 1650, Neues Palais in Potsdam. 


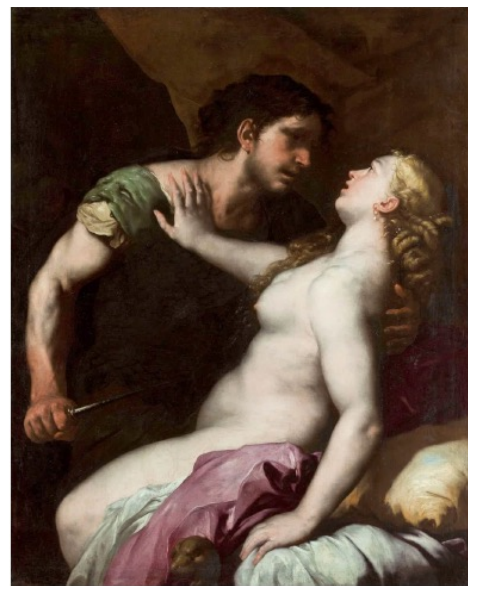

Resim 14: Luca Giordano, "Tarquin ve Lucretia”, Tuval Üzerine Yağl1 Boya, 126 x 98 cm, 1663/1664, Özel Koleksiyon 5 .

\section{Ahaşveroş'un Huzurunda Ester}

Tevrat'ın Ester Kitabı'nda belirtildiğine göre, Yahudi bir kadın olan Ester, kimliğini saklayarak Kral Ahaşveroş ile evlenmiştir. Evlilikten kısa bir süre sonra, kralın yardımcılarından Haman isimli bir soylu, Ahaşveroş’tan kendilerine boyun eğmeyen bir kavme karşı yetki talep etmiştir. İçten içe Yahudilere kin besleyen Haman, bu yetkiyle onları öldürmeyi amaçlamaktadır. Ahaşveroş ise Haman'ın planlarından habersiz bir şekilde ona istediği yetkiyi vermiştir. Haman'ın amacını öğrenen Ester ise yasak olmasına ve cezasının idam olmasına rağmen izinsiz bir şekilde kralın huzuruna çıkmış, ona Haman'ın amacını anlatmış ve halkı için merhamet dilemiştir. Ester'in cesaretinden etkilenen Ahaşveroş, kendisini kandıran Haman'ı idam ettirmiştir. Ester'in ölümü göze aldığı bu cesaret, İsrailoğullarını bir katliamdan kurtarmıştır (Ester Kitabı: 1-10).

Artemisia Gentileschi'nin olgunluk döneminde resmettiği Ahaşveroş'un Huzurunda Ester (Resim 15) adlı tabloda, mekân kurgusu bir tiyatro sahnesini andırmaktadır. Resmin merkezinde yer alan Kraliçe Ester, sadece bulunduğu alan itibariyle değil, aynı zamanda parlak sarı ve mavi kıyafetleriyle de eserin en dikkat çeken figürüdür. Halkına karşı planlanan soykırımı durdurmaya çalışan Ester, baygınlık geçirir halde hizmetçilerine yaslanmıştır. Kral Ahaşveroş ise tedirgin bir halde ayağa kalkmak üzeredir. Ester Kitabı'nda belirtildiği üzere, izinsiz bir şekilde kralın huzuruna çıkmanın idamla cezalandırıldığı bir

5- https://www.wga.hu/frames-e.html?/html/g/giordano/index.html (Erişim Tarihi: 06.11.2021). 
suç olması, Ester'i, Artemisia'nın güçlü ve cesur kadın kahramanlarından biri yapmaktadır. Judith ve Yael anlatılarında, halkını kurtarmak adına cinayet işlemeye razı gelen kadın anlatımı, Ester'de yerini halkı için fedakârlık yapan bir anlatıma bırakmıştır. Aynı konuyu resmetmiş olan Barok dönem sanatçısı Giovanni Francesco Barbieri'nin eserinde (Resim 16) kesik mekân algıs1, Artemisia'da yerini daha geniş bir mekân kurgusuna bırakmışsa da, her iki sanatçı da canlı renkleri tercih etmiş ve ikonografiye büyük ölçüde bağlı kalmışlardır. Her iki sanatçının eserindeki en önemli farklardan birini ışık etkisi oluşturmaktadır. Artemisia'nın eserinde, 1şığın kaynağı Ester'den yayılmaktadır ve diğer figürlerle mekâna kırılarak dağılmaktadır. Bununla birlikte Barbieri’nin eserinde 1şık daha dengeli dağılmıştır.

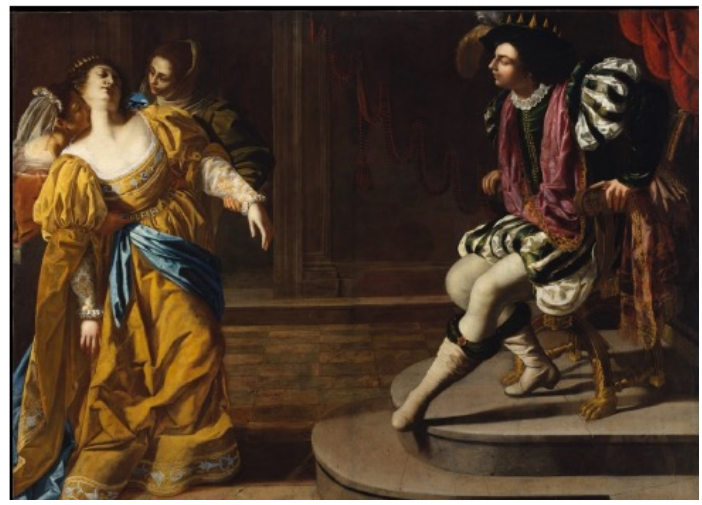

Resim 15: Artemisia Gentileschi, “Ahaşveroş’un Huzurunda Ester”, Tuval Üzerine Yağlı Boya, 208 x 273 cm, 1628/1635, The Metropolitian Museum of Art, New York.

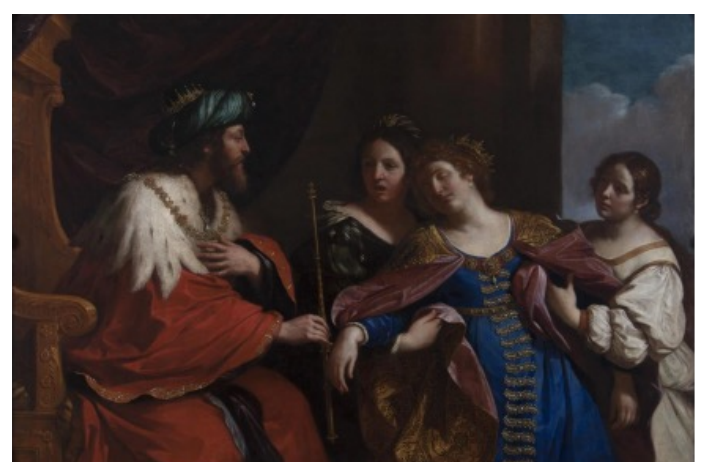

Resim 16: Giovanni Francesco Barbieri, “Ahaşveroş’un Huzurunda Ester”, Tuval Üzerine Yağl1 Boya, 156,9 x 217 cm, 1639, University of Michigan Museum of Art, ABD. 


\section{Satry ve Corisca}

Satry ve Corisca hikâyesi Artemisia'nın mitolojik konulu eserlerindendir. Öykü, Giovanni Batista Guarini’nin 16. yüzyılda kaleme aldığı Il Pastor Fido adlı eserde geçmektedir. Mitolojik bir karakter olan Satry, nymphlerden olan Corisca'ya karşı arzular beslemiş ve onu elde etmeye çalışmıştır. Ancak Corisca'dan olumlu yanıt alamayan Satry ona tecavüz girişiminde bulunmuştur. Satyr'den kurtulamayacağını anlayan Corisca ise ona bir oyun düzenlemiş ve saçlarının üzerine bir peruk takmıştır. Corisca’ya saldıran Satry, onu saçlarından tutmaya çalışmışsa da, eline geçen bir peruk olmuş ve yere düşen Satry şaşkınca ondan uzaklaşan Corisca'yı izlemiştir (Zirpolo, 2010, s.184).

Artemisia Gentileschi'nin eserlerinde sınırlı doğa manzarası olan örnekler arasında yer alan Satry ve Corisca, konusunu mitolojiden almaktadır. Tabloda, sahnenin önünde yere düşmüş ve şaşkın bir şekilde duran Satry ve hemen önünde ondan uzaklaşmaya çalışan Corisca bulunur. Resmin sağ köşesinde ağaç ve arka planın genelinde tepelikler yer alır. Eser, sanatçının manzara çalışmalarında ve perspektifte ne kadar başarılı olduğunu göstermektedir. Tabloda hareketli bir anlatım bulunur. Bu, figürlerin diyagonal olarak yerleştirilmesiyle, 1şık-gölge ve renk etkisiyle sağlanmıştır. Satry elinde tuttuğu perukla son derece şaşkın bir ifadeye sahiptir. Satry'den koşar adım uzaklaşmaya çalışan Corisca, sol eli ile etekliğini tutarak hızlanmaya çalışırken sağ eli ile de peruğun çekildiği saçlarını tutmaktadır. Satry'de görülen şaşkınlık ve öfke, Corisca'da yerini; kendini koruyabilmiş olmanın memnuniyeti ve Satry’i kandırmış olmanın mutluluğuna bırakmıştır. Daha karanlık olan arka planla uyumlu Satry'in aksine, 1şık Corisca'dan yayılmaktadır. Kıyafetleri ve renkleriyle de vurgulanmış olan Corisca, bu düzenlemesi ile tablonun merkezindedir. Satry ikinci plana atılmışken diz çökmüş hali de, Corisca karşısındaki mağlubiyetini vurgulamıştır. Bunun zıttı olarak, hareketli ve mağrur duruşlu Corisca, 1şık-renk düzenlemesi ile de vurgulanarak konunun galibi olmuştur. 


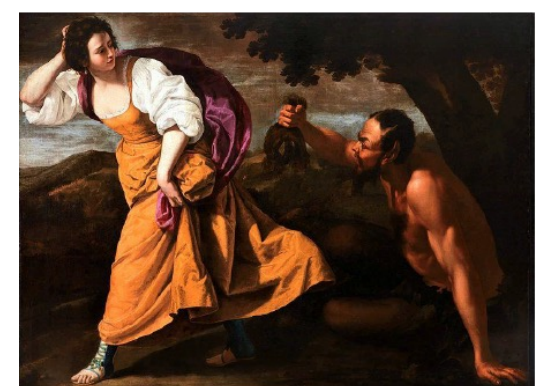

Resim 17: Artemisia Gentileschi, "Satry ve Corisca", Tuval Üzerine Yağlı Boya 155 x 210 cm, 1630/1635, Özel Koleksiyon, Napoli (Garrard, 1993, s. 35).

\section{SONUÇ}

Barok sanatın önemli ressamlarında Artemisia Gentileschi, babası Orazio'nun izinde, Caravaggist ressamlardan biri olarak ün kazanmıştır. Yaşamış olduğu trajik olayları tablolarına yansıtan sanatçı, erken, olgunluk ve geç dönem olarak adlandırılabilecek üç ayrı dönemde, farklı ruh halleriyle benzer konulu eserleri birden fazla resmetmiştir. Bunlar arasında, bu makalenin konusu içerisinde yer alan Suzanna ve Yaşlılar ile Judith ve Holofernes adlı eserler, sanatçının bireysel gelişimini en yalın haliyle ortaya koyan tablolardır. Eserlerinde Barok sanatın teatral aktarımını güçlü bir şekilde uygulayan sanatçı, 1şık-gölge etkisini renklerle bütünleştirmiş, özellikle trajik bir sahnenin işlendiği eserlerde bu unsurlarla duygusal dramayı artırmıştır. Buna rağmen bir vahşet anını bile figürlerindeki ifadelerle sıradanlaştıran Artemisia, Barok'un zıtlıklardan oluşan dünyasını en iyi yansıtan ressamlardan biri olmuştur.

Artemisia Gentileschi, Barok'un dinsel ve psikolojik birikimini, eserlerinde cesurca ele almış, kutsal figürlerinde de Rönesans ile birlikte sanatta görülmeye başlayan çıplak insan anlatımını uygulamıştır. Caravaggio ile birlikte klasik çizgilerin ortadan kaldırıldığ 1 , Rönesans'ın katı kurallarından uzaklaşıldığı Barok dönem içerisinde kendisine yer edinmeyi başaran sanatçı, eserlerinde idealize edilmeyen figürler resmetmiştir. 1610-1620 sanatçının erken dönemi olarak görülebilir. Bu y1llarda resmettiği eserlerinde, evinde izole bir şekilde aldığı özel eğitim tablolarına yansımıştır. Bilinen ilk eseri olan Suzanna ve Yaşlılar (1610-11) adlı tablosunda, mekân kurgusunun son derece zayıf olduğu dikkat çeker. Resmin arka planında yer alan sınırlı gökyüzü ile olayın 
açık bir mekânda geçtiği anlaşılan tabloda, Barok sanatın en belirgin özelliklerinden olan 1ş1k-gölge etkisi de oldukça zayıftır. Işık kırılmalar halinde değil doğrudan tüm tabloya yayılmış şekildedir. Aynı konuyu 1623 yılında da resmeden sanatçı, bu olgun döneminde sadece anlattığı öyküye değil mekâna da zenginlikler katmıştır. Figürlerini bir doğa manzarası içerisinde ele alan sanatçı, fonda kısmi bir karanlığa sahip gökyüzü, ön kısımda kırılan 1şıkla aydınlatılmış mimari unsurlar ve kullanmış olduğu renklerle dinamik bir anlatım elde etmiştir. Sanatçı bu ikinci eserinde ayrıca ikonografik göndermelere de yer vermiştir. Daniel Kitabı'nda, Peygamber Daniel'in yargıçların yalanını ortaya çıkarmak için Suzanna'y1 "hangi ağacın" altında gördüklerini sormasına istinaden, sahnenin gerisinde bir ağaca yer vermiştir. Üçüncü Suzanna tablosu ise (1649), Artemisia'nın geç dönem tablolarındandır ve Caravaggio ile ana hatları belirlenen Barok natüralizminin yansımasıdır. Kasvetli bir atmosfere sahip olan tablo, Barok'un duygusal drama ile ifade bulan kötümser anlayışını ortaya koyar.

Artemisia Gentileschi, eserlerinde güçlü kadın imajını kendiyle özdeşleştirmiş, bu özellikle Judith anlatımında ön plana çıkmıştır. 1612/13 ve 1621 kendi portresini kullanan sanatçı, Judith'e sadece gücünden dolayı değil, zekâsından dolayı da hayran olmuş ve günümüze ulaşan dört ayrı tablosunda resmetmiştir. Judith ve Holofernes öyküsünde, Holofernes, zalimliğin temsilcisidir ve arzularının peşinde koşan bir şehvet suçlusudur. Onun bu zayıf noktası Judith tarafından manipüle edilmiş ve Holofernes'in sonunu hazırlamıştır. Artemisia Gentileschi, Tassi’de gördüğü zalimliği ve iffetsizliği, kendisini Judith ile özdeşleştirerek yenmiş, Holofernes de sembolik olarak Artemisia tarafından öldürülen Tassi olmuştur. Judith tabloları, sanatçının bireysel yaşamına en çok atıf yapılan eser grubunu oluşturmaktadır. Ancak bu eserler Artemisia'nın kişisel dramını yansıtan eserler olmanın ötesindedir. İlk Judith tablosu (1612-13) sanatçının erken dönemini gözler önüne sermektedir. Holofernes' in başını kesen Judith'in kullandığı kılıç, çizgisel bir üslupla ele alınmıştır. 1621'de resmettiği Judith tablosunda ise benzer bir temayı işlemesine rağmen özellikle kılıç detayı üç boyutlu bir görselle ifade bulmuştur. Son Judith tablosunda (1623-25), sanatçının Barok 1şı̆̆ı ne denli başarılı şekilde uyguladığı görülür. Bu başarı sadece karanlık fon ve aydınlık ön kısımla meydana getirilmemiş, bir mumdan sızan ve kırılmalara uğrayan 1şık ile oluşturulmuştur. Barok'un teatral anlatımını vurgulayan bu düzenleme, sanatçının en başarılı Caravaggist ressam olarak kabul edilmesinin de sebepleri arasındadir. 
Artemisia Gentileschi, eserlerinde Barok prensipleri duygusal drama ile bütünleştirmiştir. Bu bütünlük, ifadesel anlatım, 1şık-gölge ve renk etkisiyle sağlandığı kadar figürlerin duruşlarıyla da elde edilmiştir. Barok resimde görülen diyagonal figürleri sıkça kullanan sanatçı, Satry ve Corisca'da (1630-35) yer verdiği bu düzenleme ile hem Satry'nin şaşkınlığını hem de Corisca'nın mutluluğu ve zaferini vurgulamıştır. Benzer şekilde 1650 yılında resmettiği Lucretia tablosunda diyagonal olarak yerleştirilen figürler, Lucretia'nın çaresizliğini ve savunmasızlığını en net haliyle ortaya koymaktadır.

Artemisia Gentileschi, 1611 yılında uğradığı tecavüz ve sonrasında yaşamış olduğu mahkeme süreci ile genç yaşta trajik bir yaşama sahip olmuş, ancak bu durum onu sanatsal olarak tetiklemiştir. Kabuğuna çekilmek yerine çalışmaları sonucu sanatta söz sahibi bir ressam olmuştur. Sanatçının günümüze ulaşan kırkın üzerindeki tablosunda kadın kahramanların ağırlıklı olduğu görülür. $\mathrm{Bu}$ durum, sanatçının cinsiyetinden ötürü maruz kaldığı ayrımcılığa rağmen "kadını görünür kılma” amacını yansıtır. Eserlerinde, zekâları ve güçleriyle "düşmanlarını” alt eden kadın kahramanları kendilerinden ve yaptıkları işten memnun karakterler olarak betimlemiştir. Dönem sanatçılarının, kadını "narin" ve "savunmaya muhtaç" olarak betimledikleri anlatımların karşısında, benzer konulu eserlerde Artemisia, kadınları "güçlü” ve "ne yaptığını bilen" kahramanlar olarak ele almıştır. Bu tutumun en belirgin örneği, Caravaggio’nun izinden gitmesine rağmen, onun gibi Judith anlatımında, "kararsız" ve "itici bir güce muhtaç" Judith betimlemesine gitmektense, "iş birliği yapan" ve "kendilerinden emin olan” Judith ve Abra'ya yer vermiştir. Benzer şekilde Rubens'in eserinde sadece korkan ve kaçmaya çalışan Suzanna yerine, Artemisia, yaşlı yargıçları engellemeye çalışan, kimi zaman kendini Tanrı'nın rahmetine bırakmış kimi zaman da yargıçlara öfkeyle karşılık vermiş bir Suzanna anlatımı uygulamıştır. İfadesel anlatımlarda dönemin kurallarını yıkan Artemisia, teknik açıdan da dönemin en yetkin ressamlarından biri olmuştur.

\section{Etik Beyan}

“Artemisia Gentileschi’nin Tablolarında İyi ile Kötünün Savaşı” başlıklı çalışmanın yazım sürecinde bilimsel kurallara, etik ve alıntı kurallarına uyulmuş; toplanan veriler üzerinde herhangi bir tahrifat yapılmamış ve bu çalışma herhangi başka bir akademik yayın ortamına değerlendirme için gönderilmemiştir. Bu araştırma etik kurul kararı zorunluluğu taşımamaktadır. Bu makale Etik 
Kuralları Yayın Etiği Komitesinin (Committe on Publication Ethics - COPE) yazar, hakem ve editörler için belirtilen kurallardan yararlanılarak oluşturulmuş olan Anasay dergisi etik kuralları çerçevesinde yazılmıştır. 


\section{KAYNAKÇA}

Bissell, R. W. (1999). Artemisia Gentileschi and the Authority of Art Critical Reading and Catalogue Raisonnê, Pennsylvania State University Press: Universitiy Park.

Erkan, A. (2018). Resim Sanatında 'Judith ve Holofernes' Efsanesine İki Farklı Yaklaşım (Caravaggio ve Artemisia Gentileschi). Idil Sanat ve Dil Dergisi, 7, (42), Ankara 2018, 209-215.

Elçi Akpınar, N. (2016). Görsel Ziyafete Başkaldırı: Artemisia Gentileschi, 'Susanna ve Yaşl1lar', (1610, Pommersfelden). Sanat Tasarım Dergisi, S.7, 15-19.

Cohen, E. S. (2000). The Trials of Artemisia Gentileschi: A Rape as History. The Sixteenth Century Journal, Vol.31, No.1, 47-75.

Zirpolo, L. H. (2010). Historical Dictionary of Baroque Art and Architecture (Historical Dictionaries of Literature and the Arts), Scarecrow Press, Lanham MD and Plymouth.

Mavioğlu, G. \& Karbeyaz, K. (2015). Ressam Artemisia Gentileschi ve 17. Yüzyıldan Bir Cinsel Suç Örneklemi. XII. Adli Bilimler Kongresi Isparta 04-06 Haziran 2015.

Silvers, D. A. (2010). Artemisia Gentileschi: The Heart of a Woman and the Soul of a Caesar, A Thesis Submitted in Partial Fulfillment of the Requirements Fort he Degree of Master of Liberal Arts Department of Humanities and Cultural Studies College of Arts and Sciences, University of South Florida, Florida.

Honour, H. \& Fleming, J. (2015). Dünya Sanat Tarihi, (Çev.: Hakan Abac1), Alfa Başvuru, İstanbul.

Buckley, P. J. (2013). Perspetcives Artemisia Gentileschi, 1593-1653, The American Journal of Psychiatry, V.10, I.8, 832-833.

Cumming, R. (2008). Sanat, İnkılâp Yayınevi, İstanbul.

Christiansen, K. \& Mann, J. W. (2013). Orazio and Artemisia Gentileschi, The Metropolitan Museum of Art, New York Yale University Press.

Modesti, A. (2016). A Newly Discovered Late Work by Artemista Gen- 
tileschi: Susanna and the Elders of 1652. Women Artists in Early Modern Italy Careers, Fame, and Collectors, (Ed. Sheila Barker), Harvey Miller Publishers, London.

Erkan, A. (2018). Resim Sanatında "Judıth ve Holofernes" Efsanesine Farklı İki Yaklaşım (Caravaggio ve Artemisia Gentisleschi). İdil, C.7, S.42, 209-215.

Garrard, M. D. (1993). Artemisia Gentileschi's Corisca and the Satry. The Bvrlington Magazine, V. CXXXV, N.1078, 1993, 34-38.

İnternet Kaynaklar1:

Resim 1: https://www.wga.hu/frames-e.html?/html/g/gentiles/artemisi/ index.html (Erişim Tarihi 01.11.2021).

Resim: 4: (http://www.xn--espaaescultura tnb.es/es/obras_de_excelencia/ museo_de_la_real_academia_de_bellas_artes_de_san_fernando/susana_y_los viejos_0688.html (Erişim Tarihi 25.10.2021).

Resim 5: (https://www.wga.hu/frames-e.html?/html/g/gentiles/artemisi/ index.html Erişim Tarihi: 30.10.2021)

Resim 6: (https://www.wga.hu/frames-e.html?/html/g/gentiles/artemisi/ index.html Erişim Tarihi: 28.10.2021)

Resim 7: (https://www.wga.hu/frames-e.html?/html/g/gentiles/artemisi/ index.html Erişim Tarihi: 02.11.2021)

Resim 8: https://www.dia.org/art/collection/object/judith-and-her-maidservant-head-holofernes-45746 Erişim Tarihi: 05.11.2021).

Resim 11: https://www.brushwiz.com/catalog/alessandro-turchi-yael-and-sisera-oil-painting-reproduction-24939/ (Erişim Tarihi: 15.10.2021)

Resim 12: https:/www.nationalgallery.org.uk/exhibitions/past/artemisia/ five-heroines-by-artemisia (Erişim Tarihi: 05.11.2021).

Resim 13: https://useum.org/artwork/Lucretia-Artemisia-Gentileschi-1645 (Erişim Tarihi: 05.11.2021).

Resim 14: https://www.wga.hu/frames-e.html?/html/g/giordano/index. html (Erişim Tarihi: 06.11.2021). 
Resim 15: https://www.metmuseum.org/art/collection/search/436453 (Erişim Tarihi 21.10.2021).

Resim 16: https://quod.lib.umich.edu/m/musart/x-1963-sl-2.45/1?chaperone=S-MUSART-X-1963-SL-2.45+1963_2_45A.JPG;lasttype=boolean;lastview $=$ thumbnail;resnum $=7$; $\mathrm{sid}=4 \mathrm{~d} 672 \mathrm{~d} 980600 \mathrm{fbb} 695 \mathrm{~b} 2076 \mathrm{~d} 00 \mathrm{f} 52819$;size $=20 ;$ start $=1 ;$ subview $=$ detail; view $=$ entry;rgn1=musart_all;q1=guercino (Erişim Tarihi: 21.10.2021)

https://www.britannica.com/biography/Artemisia-Gentileschi (Erişim Tarihi 01.11.2021).

https://www.catholic.org/bible/book.php?bible_chapter=13\&id=34 (Erişim Tarihi 06.11.2021)

https://www.britannica.com/topic/Lucretia-ancient-Roman-heroine (Erişim Tarihi: 06.11.2021) 
Zeki TEKIN - Emre KARAKAYA

BEYKOZ MIRI DEBBAĞHANELERI

Celal SABANCI

NIETZSCHE FELSEFESINDE ADALETIN KAYNAĞI VE IMKÂNI SORUNU

Ayşe DURAN

ARTEMISIA GENTILESCHI'NIN TABLOLARINDA IYi ILE KÖTÜNÜN SAVAŞI

Elif Şebnem DEMIRCI

ESKI ISTANBUL'DA RAMAZAN VE MAHALLE BEKÇILERI

Dursun Can EYÜBOĞLU

DEDE KORKUT’TAKI KIRK KINUK ÜZERINE BIR DEĞERLENDIRME

Melih YENER

1938-1950 YILLARI ARASINDA YAYIMLANMIŞ EDEBIYAT DERGILERINDE EDEBIYYT ELEŞTiRisi HAKKINDA DÜşÜNCELER 